\title{
Nigeria’s Quest for Industrialisation: An Inquest on the Nexus between Electricity Provision and Industrial Drive
}

Agoben Tesky Timothy*

Department of Sociology, Akoka - Lagos, Nigeria and Administrative/Research Assistant, Centre for Development Assistant Management, University of Lagos, Lagos, Nigeria

\begin{abstract}
In examining Nigeria's quest for industrialisation and the nexus it has with electricity provision, we took a brief look at Nigeria's journey, and various attempts at industrialising the country. Starting our analysis from the colonial era, it was found that, some initial significant progress such as the construction of the first rail transport system, discovery of coal and the building of the first coal powered electricity station commissioned in 1923; were made before independence. These were followed by the discovery of crude oil and the improvement of the electricity infrastructure which started from 1898. Though the first power failure was experienced in 1918 in Lagos streets, major developments continued when power stations were constructed in Enugu and other cities starting from 1925 The study also examined, how sustainable, energy provision in Nigeria is and what factor characterises a sustainable energy. Though Nigeria has the intention to develop industrially, lack of an accessible energy makes industrial development in the country difficult. In considering the effects of poor electricity provision in Nigeria, and its effect on industrial activities; the study highlighted effects such as: 'entrepreneurial migration, relocation of multinational firms, loss of foreign direct investment to other countries, premature death of infant and indigenous industries, youth unemployment and migration' as some pains that are associated with poor energy provision; which in turn culminate into industrial underdevelopment. Finally, possible solutions on how Nigeria can re-trace its steps and walk a new route to attaining industrial development were suggested.
\end{abstract}

Keywords: Industrialisation; Energy; Electricity; Industrial drive; Industrial development

\section{Introduction and Background Information}

\section{Nigeria's industrialisation Journey}

Industrialisation became part of human society in the $17^{\text {th }}$ century, when productive activities where moved from farm settlements; where humans worked with their hands, to the urban cities where humans worked with machines to produce goods. The term 'Industrialisation' refers to a social situation in which productive activities (including services) are achieved through the use of sophisticated machines and automated service procedures that reduce work-load and shift work place interpersonal relationship to highly formalized interactions.

Industrial activities in Nigeria dates back to the pre-independence era when productive activities shifted from the use of manual labour to the use of machines; and this was when steam engines where used to produce mechanical work [1]. This period also coincides with the construction of the first Nigerian rail for the purpose of transporting raw materials from the farms to the productive industries in Lagos, Ibadan and to Europe. Earliest evidence of industrial production in Nigeria was when local textile producers shifted from the use of hands, to machines, in weaving clothes and processing cottons. This was followed by the mining industries when coal was discovered in 1909 at Enugu, South Eastern Nigeria. Coal served as the oldest commercial energy in Nigeria and at its earliest stage, about 24,500 tonnes was produced [1]. This period saw increased use of coal energy to power industrial machines and rail transportation in Nigeria.

This was followed by the use of coal for power generation and the first electricity station powered by coal was commissioned in 1923 in Lagos. This feat in energy provision increase the number of goods manufactured mechanically as this impacted on the number of manufacturing activities in the country. This is because, the discovery of coals as an energy source increased the number of local industrial activities; such as Garri and Palm Oil processing which were previously done by manual labour.

However, between the period of 1943-to-1948, the country experienced a decline in the use of coal for electricity generation due to the events of the second $\left(2^{\text {nd }}\right)$ world war. Following the end of the second $\left(2^{\text {nd }}\right)$ world war, crude oil was discovered in commercial quantity at Oloibiri in present day Bayelsa State. This crude oil discovery became a temporary break-through in energy provision and industrial activities in Nigeria. This is because, the discovery of oil, brought in many oil exploration companies such the Royal Dutch now Shell Petroleum Development Company, Golf Petroleum now Chevron, SAIPEM etc. to establish their exploration companies in Nigeria. Oil discovery also increased industrial activities in manufacturing sectors like Textile, Palm Oil seed processing, Tin Smelting, Groundnut Mills amongst others. Shortly after the country's independence in 1960, industrial activities were slowed down as a result of the Nigerian Civil War which started in 1967 and lasted till 1970.

After the end of the civil war, energy demand increase as the number of manufacturing activities across the country increased. The increase in demand from the manufacturing companies led to the addition of energy source like hydropower station in the provision of

*Corresponding author: Agoben Tesky Timothy, Department of Sociology, Akoka - Lagos, Nigeria and Administrative/Research Assistant, Centre for Development Assistant Management, University of Lagos, Akoka, Lagos, Nigeria, Tel+234-17339832; E-mail: agobentesky@gmail.com

Received June 04, 2018; Accepted June 16, 2018; Published June 21, 2018

Citation: Timothy AT (2018) Nigeria's Quest for Industrialisation: An Inquest on the Nexus between Electricity Provision and Industrial Drive. Arts Social Sci J 9: 374 doi: 10.4172/2151-6200.1000374

Copyright: (c) 2018 Timothy AT. This is an open-access article distributed under the terms of the Creative Commons Attribution License, which permits unrestricted use, distribution, and reproduction in any medium, provided the original author and source are credited. 
electricity in Nigeria. According to the information sourced from the Nigeria Railway Corporation Archive, there were over 2000 industries located across the country as at 1975 (Table 1). Industrial activities improved though with a reasonable level of electricity till the end of the 1970 's. When the military took over, power and electricity generation became worse and affected industrial activities negatively. This set-back affected the Nigerian industrial sector seriously and till date, it is yet to recover fully from this set-back.

\section{A Historical Preview of Electricity Provision in Nigeria}

Under colonial rule, Nigeria started electricity generation and supply in 1896 but the first power plant was built in 1898 by the Public Works Department with a capacity of $30 \mathrm{Kw}$. As at 1899, most streets in Lagos were light by glow lamps with maximum demand reaching $24 \mathrm{Kw}$ (Edoma, Foulds and Jone, 2016). And by 1909, the installed capacity had reached $120 \mathrm{Kw}$ and the registered request was $65 \mathrm{Kw}$. By 1918, demand for electricity has increased beyond supply and street lights were turn off in Lagos for the first in 1918 due to excess load.

In 1929, the Nigerian Electricity Supply Company (NESCO) was set up as an electricity utility company, operating a hydroelectric power station near Jos, Plateau State. In 951, the Electricity Corporation of Nigeria (ECN) was established. The first 132 KV line was built in 1962, to link Ijora power station in Lagos to Ibadan power station. Since then, there have been increases in electricity infrastructure and changes both in their way of operation. The Niger Dams Authority (NDA) was established in 1962 with a mandate to develop the hydro-power subsector. It was merged with the ECN in 1972. This was however followed by the coming of the National Electric Power Authority (NEPA), the current National Electricity Regulatory Commission (NERC) and Power Holding Company of Nigeria (PHCN) as the search for stable power supply in the country continues. The Nigerian power sector faced a major setback under the military regime to the extent that, most of its hydro-electric dams were allowed to rot away, and the transmission, distribution equipment and lines became worn out until 1998 when the Federal Government initiated efforts to end NEPA's monopoly of electricity generation, transmission, distribution and sales.

\section{Energy Provision in Nigeria- How Sustainable?}

Power (i.e. Electricity) plays a vital role in the industrial development of any nation. This is because, industries require constant and uninterrupted energy (i.e. electricity) to enable them function maximally. Energy is also known to play an important role in economic growth, poverty eradication, emergence and growth of entrepreneurial activities [2]. Most $21^{\text {st }}$ century developed and developing nations use sustainable energy to power their industries. 'Sustainable Energy refers to an energy source that is easily accessible, affordable, durable, environmentally friendly and can be used to develop or improve othersources of energy'. This is because, future economic growth and industrial development depends on long-term availability of a sustainable energy [2]. The energy situation in Nigeria does not meet the criteria of what characterises a sustainable energy. This is because, at present, Nigeria has very poor electricity condition. While many countries of the world have stable power supply and can be accessed, that of Nigeria can be hardly accessed by ordinary citizens let alone manufacturing industries. Though the country has an installed capacity of about 8,500 Mega-Watts (using the 2014 data of Power Holding Company of Nigeria-PHCN), the available capacity was 4,949 Mega-Watts and the actual average generation was less than 3,900 Mega-Watts (see www.en.m.wikipedia.org/wiki/list-of-station-inNigeria). This was dropped to an all-time low capacity of 2,662 MegaWatts on January 22 nd, 2017 (see Premium Times Nigeria, January $\left.22^{\text {nd }}, 2017\right)$. According to the Nigerian Guardian Newspaper of April $30^{\text {th }}, 2016$; it was emphasized that, Nigeria needs about 160,000 MegaWatts to have un-interrupted power supply. Going by the above data, it shows that for electricity to be accessible and function effectively, Nigeria needs about 160,000 Mega-Watts; but at present, Nigeria currently generate only about 3,900 Mega-Watts (using PHCN 2014 data). This shows the country needs an additional 156,000 Mega-Watts to achieve uninterrupted power supply. What this means is that, the current energy source of electricity in Nigeria, is not accessible since the meagre 4,000 Mega-Watts cannot serve the needs of the citizens let alone the industrial sector. What this suggests is that, industrial activities will be disrupted and this will affect economic growth or industrial development. Also, it has been discovered that the meagre energy provided in Nigeria is not even affordable. This because the bills charged by the Power Holding Company of Nigeria (PHCN) and the various private distributors are exorbitant. This is akin to the fact that; the electricity billing system are poorly generated since there are no electric metres or pre-paid cards to monitor usage. The

\begin{tabular}{|c|c|}
\hline City & Principal Activities \\
\hline Kano......277 & Groundnut mills, textiles, perfumery, plastics, tanning, minerals waters, carbon dioxide, bata shoes, releigh industries, retreading \\
\hline Kaduna......550 & Textiles, brewing, London Brick pre-cast concrete, ordinance, building materials. \\
\hline Zaria......145 & Oilseed processing, Nigerian Tobacco, toiletries, bicycle assembly. \\
\hline Jos.....60 & Tin smelting, pump assembly, twill jute snacks. \\
\hline Gusau.......75 & Textiles, rail head for Sokoto cement. \\
\hline Maiduguri......79 & Oilseed processing, abattoir not within the estate, Chad fishery to be developed. \\
\hline Ilorin......317 & Philip Morris Tobacco, United Matches, Tate and Lyle. \\
\hline Port-Harcourt......200 & $75 \%$ industrial, $25 \%$ residential. Alcan Aluminum, paints, enamelware, tyres and tubes, Costain (WA) furniture, Textiles, soap, pharmaceuticals. \\
\hline Aba......5 & Brewing, ceramics, not rail served. \\
\hline Umuahia.......31 & $\begin{array}{l}\text { Turners Asbestos cement paper and sheet, iron and steel mill, Niger gas factory, Textiles, iron and steel, mineral waters, bus bodies. } 50 \% \text { residential } \\
\text { and } 50 \% \text { industrial. Not rail served. }\end{array}$ \\
\hline Onitsha.......1518 & \multirow{2}{*}{$\begin{array}{l}40 \% \text { industrial, } 60 \% \text { residential. Textile, tyres, asbestos cement, enamelware, biscuits, paints, mosaics, Guinness, Aluminium products, drugs, } \\
\text { galvanized work, livestock feeds, Bridon Group (Nigeria) wire-mesh and barbed wire, ICl, Plastic pipes. }\end{array}$} \\
\hline Ikeja......750 & \\
\hline Mushin......230 & Milk recycling, bicycle assembly, mattress factory, furniture, metal windows, not rail served. \\
\hline Ilupeju......67 & Light industries, rail served by Oshodi station. \\
\hline Apapa......230 & $\begin{array}{l}\text { Established by Lagos Executive Development Board (LEDB), flour milling,automobile assembly, margarine, Sunlight/Lifebuoy/Lux toilet soaps, } \\
\text { Nigerian }\end{array}$ \\
\hline Iganmu......200 & ropes, Metalbox, West African Distillers, West African Cold Store, IBRU Seafoods.Developed by LEDS, Star Brewery. \\
\hline
\end{tabular}

Source: Archive of Nigerian Railway Corporation (1997) cited in Edomah, Foulds and Jones 2016).

Table 1: showing industrial activities in Nigeria between 1970 to 1975. 
non-accessibility, non-affordability and unavailability of the electrical energy source in Nigeria, makes it difficult for it to be used to develop other sources of energy like solar, wind or hydro energy since there will be no electricity to power the machines needed for their operations. All these amongst other factors makes the electrical power provided in Nigeria to be very unsustainable; thus impacting negatively on industrial activities and the development of the industrial sector. This poor energy provision disrupts industrial activities and slow down the country's industrial development. To look at the degree with which industrial activities has been hampered or improved in Nigeria, let us examine how practicable; is the quest for industrial development in Nigeria.

\section{The Quest for Industrial Development in Nigeria - How Practicable?}

Before discussing how practicable or possible the quest for industrial development in Nigeria is; let's get an understanding of what industrial development entails. The term 'INDUSTRIAL DEVELOPMENT' refers to a transition of productive activities in a society (i.e. tangible goods or services) from human physical-labour operations to the use of locally developed but manually operated machines; which are improved upon to develop modern and electrically operated machines for large scale production. It also involves the transition and increase of a society's manufacturing activities from small scale-to-medium scale and large scale industries. In other words, for industrial development to take place in a country, there must be a progress of her own productive activities from human-labour operations to her own locally manufactured and manually operated machines which will in turn be improved upon to develop an electric or automated productive machine that will ease productive activities. Thus, a country which though produced her goods but with all machines imported is not qualified to be called an industrialised nation. To get a better understanding of this definition, let us examine or look at how printed documents or written text were produced. Documents or written text such as the Bible, Koran, Letters or other earlier books were written with hand, their production was improved upon when the manual characters (alphabet and numbers) fixing machine was produced. This was followed by the development of typewriters, stencil duplicating machines, lithograph printers, desktop computers, laptops and currently tablets. This progression is what constitutes industrial development; from primitive manufacturing and production processes to modern sophisticated production processes. It can also be seen from the transition of using wagon or carts attached to animal for transportation to the use of automatic, electronic or self-driven cars; or from the use of canoes to the use of modern speed boats or ships.

The above analysis is what constitute industrial development or the industrialisation of a country. Using the Nigerian industrial environment, we can see or say that, there is no visible industrial development in the country. This is because, many of our productive activities, such as farm clearing, harvesting, planting are still done manually; and other manufacturing or farming activities and some of its products including the large-scale farming machines are imported. Our Tri-cycles (popularly known as KEKE-NAPEP) and motorcycles are imported from India, a country which shares the same status with Nigeria as developing country. India has progressed into manufacturing cars such as TATA, INDIGO but Nigeria still imports all her cars and has only one indigenous company that assemble very few imported car parts. The poor energy provision which has hampered the industrial development of the country, has also affected the sociological conditions of other sectors of the country. Let take a look at how these has affected industrial activities and other areas of the society.

\section{Effects of Poor Energy Provision on Nigeria's Industrial Activities}

\section{Migration of young entrepreneurs}

According to Ayobade, one of the major effects; poor energy provision has on Nigeria's industrial activities or development is, the migration or relocation of indigenous entrepreneurs or investors to nearby African countries such as Ghana [3]. Young Nigerian entrepreneurs who have invested in small scale manufacturing industries cannot do business easily in Nigeria as a result of a lot of unfavourable factors. This is because the absence of constant power supply increases the cost of doing business in Nigeria. This increase in cost of doing business due to the absence of constant electricity, has made young enterprises to move to other nearby West African countries where there's relatively improved power supply and ease of doing business. Ayobade emphasized that, these inadequacies enabled government of neighbouring countries like Ghana to lure industries from Nigeria with incentives such as 15 years tax exemption for corporate tax and a long-term interest free bank loans facilitated by the Ghanaian government through the Ghanaian Investment Promotion Council (GIPC). The GIPC also had the mandate of, swaying Nigeria's entrepreneurs interest to their country by offering them 10 years of uninterrupted power supply as an incentive [3]. Aside from Ghana and other African countries, countries like Canada, Austrialia and Portugal now lure entrepreneurs of other countries especially Africa (with Nigeria as the main target) by promising them permanent resident permit (see www.immigration.ca/investors-rquirements). A number of Nigerians have applied for the Canadian and Australian investors offers; and have relocated their capital from Nigeria. There had been cases of some Nigerian bloggers, printing press operators, fashion designers and IT software developers, who relocated from Lagos but operate their businesses from Ghana or Benin Republic. The migration of Nigerian entrepreneurs to other countries is slowing down the pace of Nigeria's industrial development and it is under developing the industrial sector as many small scale manufacturers cannot find it cost-effective to do business in the country. Many young entrepreneurs who cannot relocate to other countries run away from entrepreneurial activities and resort into paid employment to make ends meet again. Hence, it is right to say that, the migration of indigenous entrepreneurs from Nigeria is a sign that industrial activities in Nigeria are retrogressing.

\section{Relocation of multi-national firms}

Another glaring effect of poor energy provision in the industrial activities of Nigeria; is the re-location of multi-national firms from the shores of Nigeria to other neighbouring countries such as Ghana, Benin Republic, Cote-D'Ivoire etc. Olufemi also corroborate this when he opined that, the reason why many multi-national firms are leaving Nigeria is because, they want to enjoy relatively constant power supply provided in these countries [4]. According to excerpts from the study of Ayobade, some multi-national companies such as DUNLOP, Michelin Tyres, were forced to close down their business in Nigeria as a result of erratic power supply which often result to high cost of business operations for them [3]. The decision of Michelin Tyres to close down business operations despite 45 years of industrial activities in Nigeria; with an option to relocate productive plant to Ghana or elsewhere is a pointer to the fact that, the Nigerian power sector is incapable of providing the sustainable energy needed for the industrial advancement of the country [3]. The reason behind this verdict is that, Nigeria has 6,000 Mega-Watts installed capacity of electricity but can only generate just 2,000 Mega-Watts; this action emanating from the 
Nigerian power sector, depict what inefficiency in the real sense stands for [3]. This is not even compared to the country actual electricity need of 60,000 Mega-Watts for her total population and industrial activities. Ayobade opined that, among industries contemplating relocating from Nigeria to Ghana are Unilever Plc., PZ Cussons and the major reasons they gave were high-cost of production as a result of independently generating their own electricity [3]. Also considering relocation out of the country due to high cost of business operation is Guinness Nigeria Plc., a brewing firm that has operated in Nigeria for a long time. It should be of interest that, as at the time writing this study, Michelin Tyres, Dunlop, Part of Nestle Plc, Coca-Cola has relocated their production plants and major business operations out of the country but only export finished products from their present location to the Nigerian market. The above highlighted examples show that, sustainable and constant electricity generation play a vital role in the development and expansion of a country's industries but in the absence of that, the industrial sector will be stagnated.

\section{It kills the development of infant industries and local businesses}

For infant industries and local businesses to develop, they need constant energy or electricity to produce at maximum capacity. This has been the case with all developing countries such as India, Singapore, Malaysia etc. that are now making industrial breakthrough. Due to the epileptic power supply in Nigeria, many infant industries and local businesses in the country have not been able to improve their productive capacities; so as to, at least, have a competing edge with the few foreign companies in the country. Oyedepo re-iterates that, for basic development to take place at the local level; even in areas such as healthcare, telecommunications or quality education, electricity is required [2]. Many of our indigenous local industries such as rice mills or textile manufacturing line that depend on the country's electricity have been forced to closed-down their businesses because of high cost of operation. They are also unable to compete with products from foreign countries since the price of goods manufactured at home were higher than the imported ones as result of the high production cost our home industries incurred. It has been estimated that about 170 plants of Nigerian Textile Manufacturers have been shut-down due to high cost of production arising from poor electricity provision [3]. Also, the poor energy provision in Nigeria has killed the dreams of Nigeria's young industries to attain the status of multi-national firms. These above highlighted views corroborate and run in pari- passu with the views expressed by Emeka when he said: "lack of electricity has led to the closure of some infant indigenous industries and has stifled the growth of small-scale businesses". For instance, though Nigerian Breweries still bear the name Nigeria Breweries, the major share of the company's ownership is owned by Heineken-The Netherlands giant brewery company (see https://en.m.wikipedia.org/wiki/NigerianBreweries). To show the extent which Nigeria's infant industries are prematurely murdered due to poor energy culminating into high cost of production, Heineken through its media website announced that, it has acquired 5 Nigerian local breweries of which Sona and Consolidated breweries in Ogun State are included. In a similar vein, Guiness Nigeria also acquired Orijin Nigeria Distillers-an indigenous brewing company who were the original producer of the Orijin brand drink. This acquisition is in a view to ensure that, they the foreign breweries take over the Nigerian drink market without any competition from the local or indigenous breweries who are struggling to survive. Many of our one time indigenous and vibrant industries that would have develop to become standard international firms, have also died due to unbearable operational cost as a result of sourcing for external energy. Examples of some Nigeria's companies that have died due to high cost of sourcing for external energy are: Starcomms with the slogan, 'We speak Your Language depecting its Nigerianism. Others are Multi-Links, Reltel and not too long Visafone. This is aside the 10 Textile industries with a strength of 4,000 employees that closed-down business operations due to inability to meet operation cost [3]. This also affected indigenous broadcasting firms like H-ITV that were competing with DSTV. These former local Nigerian owned telecommunications company cannot survive the heated business environment in the telecommunications sector. This is because, as found out in one of the study conducted in Nigeria; MTN - the largest telecommunication (though not-indigenous) company operating in Nigeria, spends \$5.5 Million Dollars a month to fuel (i.e. power) it's over 6,000 installed base stations generators [5]. This enormous cost for energy provision alone, can cripple the activities of any infant industries operating in the telecommunication sector and this is evident in how most of our telecommunications industries died.

\section{Loss of foreign direct investment to other countries}

One of the characteristics of a good international market or business economy, is its ability to attract or detract foreign investors into her economy. When a country has functional infrastructural facilities and large markets, foreign investors will be attracted to such a country for investment. In the case of Nigeria, we have the latter and not the former. This is evident from the fact that Nigeria is rated 167 out of 189 countries using the indices of 'with ease of doing business' [6]. Though with the largest market in Africa, Nigeria still struggle with poor and dysfunctional social amenities like poor out-dated rail transport system, non-functional electricity and unsafe pipe-borne water amongst others. If all these aforementioned social amenities including functional electricity is what drives industrial development, and it can in turn affect other over-head costs, then their availability and functionability will improve the Nigerian business environment and propel industrial progress. This re-affirm the sentiments of Uduma and Arciszewski when they opined that, there are extra investment cost when an organisation provides energy and basic amenities for themselves and this could be a burden for them and a burden that will scare new investors away. Because of this peculiar problem (i.e. lack of a functional source of electricity) with the Nigerian market, many foreign investors choose to invest in other neighbouring countries, with the aim of; shipping its finished products to the Nigerian market because of her economic value of controlling the largest market size in Africa. A number of foreign investors which would have been attracted to do business in Nigeria have jettisoned investing in the country due to too much uncertainties. For instance, the Nigerian-American Chamber of Commerce (NACC) report found at www.ripplesnigeria. com says: "about $25 \%$ percent of Nigeria's foreign investors pulled their investment worth $\$ 450.34$ Billion Dollars assets out of the country between September, 2015-to-October, 2016". In the words of NACC Chairman, Chief Olabintan Famutimi he said: "There are more closure of operating centres in Nigeria by foreign and indigenous business owners". He listed the foreign investors to include: United Airlines, Iberia Airlines, Truworths International Limited, Mitsui O.S.K. Line, Messina Line, Nippon Yusen Kasha, Taiwan's Evergreen Line, Aberdeen Asset Management Plc., and Ashmore Group Plc.. In another report but similar issue found in the Nigerian Guardian Newspaper of March $3^{\text {rd }}$, 2017, the Managing Director of Nigerian LNG (Liquified Natural Gas) said: "the company loss a foreign investment deal of \$25 Billion Dollars which is worth N10 Trillion Naira due to the delay and non-completion of the Train-7 plants. The company (i.e. Nigeria LNG) 
further said that, another potential loss of this foreign investment they missed is the potential loss of about 18,000 jobs required for the construction of the Train 7 plants". (see The Nigerian Guardian Newspaper-Business News of March $3^{\text {rd }}$, 2017). This alarming figures and disturbing cases show the impact, of how a poor power sector can scare away foreign investor that would want to do business in an economically viable country like Nigeria.

\section{High level of youth unemployment and trans-border migration}

Since a country's sociological condition determines her industrial condition, and it's industrial condition in turn affect the sociological and living condition of her citizens, then high level of unemployment and youth migration cannot be detached from a country who is experiencing industrial under-development. One of the grave and visible sin arising from Nigeria's poor energy provision and industrial underdevelopment is high level of unemployment and trans-border migration among the Nigerian youth populace. From the previous examples we have highlighted above, it can be seen that several multinational firms, indigenous companies, small scale business entrepreneurs and foreign investors have either close-down their businesses in Nigeria due to inaccessibility to energy or relocated their operation to other countries. The resultant effect of their action is that, most if not all the staff working with them will be laid-off and become unemployed. To know the seriousness of this issue, let's consider some facts from available data on the issue of youth unemployment in Nigeria. According to the National Bureau of Statistics, 54\% percent of Nigerian Youths were without a job as at 2012. And as at February $27^{\text {th }}, 2017$ according to information exhume from the Nigerian Thisday Newspaper, through data provided by the National Bureau of Statistics, it gave the total figure of Nigeria's Labour Force to be 78.48 Million and out of these figure (i.e. out of the78.48 Million) 38.2 Million individuals are youth. It is surprising and pathetic to know that, $42.24 \%$ percent of the 38.2 Million who are youth between the ages of 15-35 are unemployed. (See the Nigerian Thisday Newspaper February $26^{\text {th }}$, 2017 - 'Dealing with Youth Unemployment'). This alarming rate of youth unemployment shows that, more than 5 out every 10 Nigerian youths are unemployed as at the time of this study. In response to this huge unemployment rate, many Nigerian youths engage themselves in nefarious social anomaly such as kidnapping, arm robbery as can be seen from the recent high rate of kidnapping in the country as well as activities of the BADOO cultist group in Ikorodu, Lagos. Others who possess working skills and higher education but could not engage in crime, travel to other countries for employment purposes. For instance, the Nigerian Guardian Newspaper of $24^{\text {th }}$ April, 2015 listed unemployment as the major factor (aside other factors like poor governance) why Nigerian youths are migrating to Asia, European, Middle-East and African countries inclusive. The huge number of youth unemployment in Nigeria plays a major role for trans-border migration among youths. As at 2001, an estimate carried out by De Haas cited in the Isiugo-Abanihe and IOM report, shows that, a total of 293,844 Nigerians put together were living in the United Kingdom, Spain, Italy, Greece, Portugal, North America and other European countries [7]. These figures according to IOM and Isiugo-Abanihe were just those officially reported [7]. It is clear from the above evidences and analyses that Nigeria's rate of youth unemployment is very high due to the retrogression of industrial activities in the country.

\section{Industrial Development in Nigeria - Possible Routes to Actualisation}

Though Nigeria is on a temporary set-back in her quest to attaining industrial development, there could be a possible come-back if some practicable steps, which could yield productive and replicable results are taken by the Nigerian government. In order for Nigeria to actualize her aim of becoming an industrialize nation, the government and industrial policy makers of this country should retrace their step and take a new route with some of the highlighted suggestions below.

1. First, the Nigerian government should focus at least $60 \%$ of her national budget on the power sector for at least three (3) years. So that the entire power sector can be overhaul and non-performing stations should be put up to date with functional facilities. This is to ensure that stale and underperforming equipment are replaced and completely discarded. The reason for this suggestion is because, once the power sector is functional every other sector of the Nigerian economy will reap its dividend and continue to progress industrially too.

2. Secondly, to ensure that we replace high level of import and increase the number of indigenous productive activities in the country, there should be compulsory two years trade education for secondary students after a compulsory 5 years of normal schooling, this model of education is adopted by countries like Germany and Togo in Africa $[8,9]$. This is to ensure that, our youth learn productive skills in secondary school before preparing for higher education or opting to start their own small-scale establishment.

3. Thirdly, Students who attends Technical Colleges should be given priority and channelled to take courses in Engineering, Building, Architecture or any other technical fields. Also, talented and exceptional students in Nigerian Technical Schools should be sponsored to other foreign universities that specialises in Technical and Practical Teaching of machine building. This will enable the students to gain first hand machine building knowledge and transfer same to other youths when they are back. All these are to ensure we tap from the knowledge and ideas of country's that produces their own machines as this is the best way we can attain industrial development and self-sufficiency.

4. Fourth, the Entrepreneurship development programme or course in our universities should be re-designed to start from year one and we should ensure that we collaborate with our local artisans such as fashion designers, motor-mechanic, builders/bricklayers, barbers, photographers etc. so that they can train our undergraduate student in the Entrepreneurship courses in any trade area of their choice, this is to enable them garnered skills while they are in school, thus paving the way for young entrepreneurs and would be inventors.

5. Finally, Government should sponsor policy makers like Sociologists, Psychologists, Economists etc. who have in-depth knowledge about industrialisation, to study the economy and industrial activities of countries who are making visible significant progress in the field of industrial development.

\section{Conclusion}

Having examined and analysed the inception of industrial activities in Nigeria and the major factor that inhibit the progress of industrial activities in Nigeria, it is pertinent to note that, the current challenges facing the country quest to be among industrial progressing nation; is not a permanent failure but a temporary set-back. This is so because, if we make the right industrial propelling policies as a country and invest honestly and truthfully in the power sector, we can rejuvenate the almost dead Nigerian industrial sector and ensure we bring it back to life again. Priority should be given to the development of local industries and the Nigerian government should provide an enabling environment including incentives that will impact our young industries 
Citation: Timothy AT (2018) Nigeria's Quest for Industrialisation: An Inquest on the Nexus between Electricity Provision and Industrial Drive. Arts Social Sci J 9: 374. doi: 10.4172/2151-6200.1000374

to grow to international standard. Also, Government should be honest with leadership as this one of the back-bone that can improve the social conditions of the Nigerian society, and once the sociological conditions are improved; industrial development will begin to pick up gradually.

\section{References}

1. Edoma N, Foulds C, Aled J (2016) Energy Transition in Nigeria: The Evolution of Energy Infrastructure Provision (1800-2015)

2. Oyedepo OS (2012) Energy and Sustainable Development in Nigeria: the way forward.

3. Ayobade A (2011) Micro-Credit: An Amelioration of Poverty for Small-Scale Entrepreneurs in Nigeria. Journal of Sustainable Development in Africa Clarion University of Pennsylvania Clarion Pennsylvania Vol-19.
4. Olufemi JO (2015) The Effects of Electricity Consumption on Industrial Growth in Nigeria. Journal of Economics and Sustainable Development.

5. Uduma K, Arciszewski (2010) Sustainable Energy Development: The key to a Sustainable Nigeria.

6. The Nigerian Vanguard October $26^{\text {th }}(2016)$.

7. IOM, Isiugo-Abanihe (2014) Migration in Nigeria: A Country Profile. A Publication of the International Organisation for Migration (IOM) prepared by Isiugo-Abanihe CE.

8. The ASCE Global Centre of Excellence in Computing Fairfax (2017) VA 22030 USA Premium Times Nigeria.

9. The Nigerian Guardian Newspaper of April 30 2016 . 